\title{
Understanding Structural, Governance and Regulatory Incen- tives for Improved Utility Performance: The Case of Kenya and its Kenya Power.
}

\author{
Peter Twesigye ${ }^{1, *}$
}

1 Power Futures Lab, Graduate School of Business, University of Cape Town, Cape Town, South Africa; peter.twesigye@uct.ac.za

* Correspondence: peter.twesigye@uct.ac.za; p.twesigye@gmail.com; Tel.: +27 (0)63 3721108; +256 (0)774999660 (P. Twesigye)

\begin{abstract}
The power sectors in most African countries face an enduring problem of utility performance - electricity utilities have failed to deliver adequate, reliable and competitively priced electricity to support economic growth and improve the welfare of their populations. Despite more than two decades of power sector re-forms, outcomes have been varied and often disappointing. Using a case study de-sign, we explore the five key enduring power challenges. The research utilizes a more powerful analytical framework that combines power sector reform theory and principal-agent theoretical lens to explore the experience of power sector reforms in Kenya and provides a deeper understanding of drivers of utility performance and reform impacts. Empirical findings show that the structural, governance and regulatory reforms that previously created incentives for improved utility performance are increasingly threatened by political influence. Kenya Power's financial viability has deteriorated in recent years and the regulator has been undermined. One of our major conclusions is that when the relationship between the principal (government) and agent (utility) is well understood and the agent is properly incentivized, performance improvements are possible. However, when the government undermines or muddies those incentives through conflicting political interventions, performance improvements can be reversed.
\end{abstract}

Keywords: Utility; Reforms; Governance; Regulation; Incentives; Agency; Liberalization; Performance

\section{Introduction}

Kenya's history and experience with power sector reform is unique and different from other countries in the region thus affording the potential for interesting and valuable insights. Kenya was one of the few African countries that decided early on to unbundle generation from transmission and distribution, with the creation of Kenya Electricity Generation Company Limited (KenGen) and Kenya Power and Lighting Company Limited (KPLC ${ }^{1}$. Uniquely, both KPLC and KenGen are listed on the Nairobi Securities Ex-change (NSE) although the government retained majority stakes $50.1 \%$ in KPLC and $70 \%$ in KenGen). One of the consequences of unbundling generation from transmission and distribution has been the removal of the potential for a conflict of interest ${ }^{2}$ which arises where a vertically integrated, national utility is both a generator and the single buyer for IPPs.

Supported by a national planning process for least-cost generation expansion, KPLC was able to translate plans into timely initiation of competitive bids for new power [1]. Through building in-house capabilities, KPLC ran a series of successful tenders, mostly

1 KPLC was rebranded as Kenya Power in 2011, but for uniformity in this paper, we refer to it as KPLC

${ }^{2}$ Competing in procuring new generation capacity and power dispatch to the grid 
for thermal power, with subsequent tender rounds yielding even lower prices, and plants generally being built on time. Kenya ranks amongst the countries with the highest number of IPPs in sub-Saharan Africa and currently is in the fortunate position of having sur-plus capacity. However, these planning and procurement capabilities have eroded and dissipated somewhat in recent years. Kenya was also amongst the early countries to establish an independent electricity regulator, which later was converted into an energy sector regulator [2]. In addition, the utility has built a strong institutional culture and technical capacity fostered through targeted capacity development and training and supported by involved leadership. The utility was subject to a private management contract for a short period. These reforms, especially the partial listing of KPLC, create an interesting set of governance and regulatory incentives for improved performance.

Despite these advancements, the power sector in Kenya still faces enduring challenges, including weaknesses in the transmission and distribution segments of the system; the politicization of long-term planning; an emerging surplus of power generation capacity, and the need to integrate more variable sources of energy without affecting system stability [3]. In addition, recent gains in electricity access and generation capacity have come at a cost: threats to the financial sustainability of KPLC [4] and KenGen have necessitated periodic debt restructuring. KPLC's profitability which, for decades, was steadfast has, in recent years, been in decline, unable to meet its debt covenants, and its solvency and creditworthiness are increasingly threatened [5]-[7]. Recent governance challenges saw the termination of the entire senior management team in 2018 and the board in 2020 [8].

This paper examines the experience of Kenya through the lens of power sector reform and principal-agent theory, yielding new insights, explanations and knowledge on the relationship between power sector, regulatory and governance reforms and how they impact on performance - mainly increasing access and delivering adequate and reliable electricity at competitive prices through a utility which strives to be technically efficient, financially viable, creditworthy and able to attract investment into the sector.

The Kenya case study provides insights on the interaction between power sector reform, regulatory and governance frameworks and utility performance that can be generalizable in Africa. We use an analytical framework that combines the power sector reform and the principal-agency theories which enables a deeper understanding of how strong governance and structural reforms have provided stronger incentives for improved performance.

Power sector reform theory is partly helpful in explaining the differences in utility performance, but this paper goes further in seeking to understand the way these reforms alter governance and regulatory incentives for im-proved performance. This paper proposes a new analytical framework that will contribute to new knowledge in this field.

\subsection{Enduring power challenges in Africa in brief}

The SSA region including Kenya is faced with five key enduring power challenges which have, in combination, constrained delivery of electricity services on a sustainable basis.

(i) Installed generation capacity is inadequate, with most countries in the region having power systems smaller than 500MW [9].

(ii) Electricity access rates remain low, with $45 \%$ of households not being connected to the grid [10], [11].

(iii) Even for those with a connection, power cuts and load-shedding are a frequent occurrence due, to inadequate generation capacity and inadequate investments and maintenance in the network [1], [12].

(iv) The cost of electricity (median tariff is US $\$ 0.15$ per kilowatt-hour) in Africa is among the highest in the world [13], [14] and households and enterprises often have to 
rely on expensive diesel backup power generation to meet their electricity needs, costing some economies between 1\%-5\% of annual GDP [1], [12], [15].

(v) The above problems arise because of the poor performance of utilities. Technical inefficiencies are reflected in high losses and inefficiencies in CapEx execution [16] which result in the high cost and poor quality of service [12], [13]. Commercial inefficiencies are reflected in poor billing and collections, leading to chronic indebtedness [17], underpricing or below-cost tariffs and poor customer service leading to low willingness to pay.

As a consequence, most incumbent electricity distribution companies (DisCos) are financially distressed and dysfunctional. The resultant revenue gap imposes an additional burden on already strained government fisci - a trend that has persisted in most SSA countries.

A response to these challenges has been utilizing power sector reforms involving corporatization, regulation, restructuring, competition and private sector participation.

\subsection{Linking Power Sector Reforms to Utility Performance}

Poor technical and financial performance was the defining feature of many electricity supply industries in Africa by the end of the 1980s and 1990s [18], [19]. Drawing on the successful electricity sector liberalizations in the U.S and England, the World Bank began to actively promote significant structural changes in developing countries' electricity sectors, alongside the broader structural adjustment programmes for liberalization [20], [21]. Over time, the reforms came to be known as the 'standard model' and involved the establishment of an independent regulator, the unbundling of generation, transmission and distribution, private sector participation, and competition.

Despite many countries initially committing to the 'standard model', these reforms have progressed only partially, and differently, across the region, resulting mostly in hybrid power market structures, in which dominant incumbent state-owned utilities continue to operate alongside independent power producers [18]. In some countries, reforms have also incorporated private management contracts or long-term concessions [22]. These hybrid market structures have resulted in new governance and regulatory frameworks and have generated new operational and commercial issues that have impacted performance. In addition, the reforms have sent different sets of signals around incentives in the structural, governance and regulatory frameworks of utilities, unlike what was initially envisaged in the pioneering standard model reforms.

The impact of these reforms on utility performance has been mixed. Several studies have been conducted to establish the reform impacts on performance [23]-[26], mostly narrow in scope and using econometric/statistical approaches to explore relationships between a limited number of variables. Yet, the design of power sector reforms involves a range of interventions which play out in different ways depending on the political economy and country context. These need to be adequately taken into account.

This paper provides a deeper exploration about how the core reform steps of regulation, restructuring, competition and private sector participation impact utility performance in Kenya to answer the following questions:

(1) How can we explain and understand the varied utility performance outcomes in Kenya?

(2) To what extent does principal-agent theory, combined with power sector reform theory provide a more powerful analytical framework to better explain the varied performance?

(3) In which ways do the power sector reforms alter principal-agent relationships and incentivize improvements in performance in Kenya?

The paper continues with presentation of the materials and methods in section 2, followed by a description of the theoretical and analytical framework in section 3 . The analysis of reforms, governance arrangements and operational performance provides 
quantitative and qualitative results in section 4 . The discussion and conclusions are presented in section 5 .

\section{Materials and Methods}

The research utilizes a qualitative explanatory case study with embedded mixed methods of data collection (quantitative and qualitative) and analysis [27] to investigate drivers of utility performance, governance arrangements and principal-agency relationships. Cases are good at revealing the complete picture which takes into account the context (Pettigrew, 1992; Yin, 1994) and identifies causal links/operational pathways through the rich and in-depth information, firmly rooted in the original evidence [28]. This case offers deeper insights into structural, governance and incentive arrangements within utilities, and can explain potential causal principal-agent pathways of institutional and organizational changes that are difficult to identify with econometric and statistical models [29].

\subsection{Data Collection and Analysis}

Two methods of data collection were embedded within the case studies: Quantitative data collection was conducted first from secondary and primary data sources, including annual reports, sector wide data and multilateral development agency databases. The data was analyzed manually using Excel spreadsheets.

The qualitative phase involved qualitative document analysis (QDA) of secondary data [30]. The documents included contracts and agreements, regulations and licenses, sector policies, annual reports, management reports backed by primary data, utility policy documents and board charters, company fact sheets, energy sector publications and reports, archival records, observational data from meetings as well as official media publications from utilities and regulatory agencies. Document analysis allowed for the identification of conceptual categories from the literature on power sector reforms and formulation of emerging themes of the most influential factors on utility performance and their causal relationships with the outcomes (measured as KPIs).

These relationships were further explored through interviews. A purposive sample of 10 utility top executives and senior managers - high priority and highly knowledgeable interviewees who viewed the focal phenomenon of utility performance, governance and incentives frameworks from diverse perspectives - were interviewed to obtain both retrospective and real-time accounts and reasons behind the utility performance phenomena, governance arrangements and principal-agency problems/relationships.

To limit information bias, a sample of two regulatory authority senior executives or managers helped to validate the information provided by utilities. Combining these methods was necessary to allow for a direct assessment as well as for data validation and rigor. The qualitative data was analyzed using NVivo software and triangulated [31].

\section{Theoretical and Analytical Framework}


Figure 1. The Analytical Framework

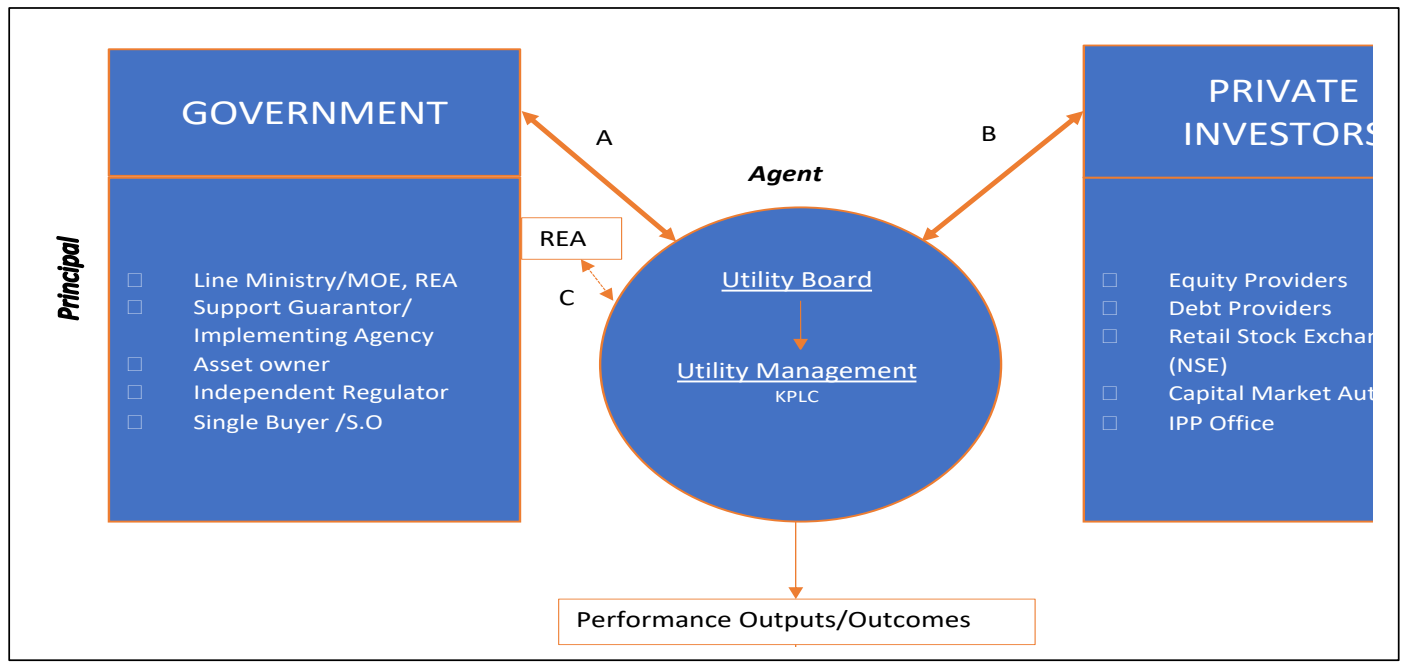

Using the positivist principal-agency theoretical lens [32], the analytical framework in the figure above presents a governance structure that is used to explain the inter-relationships of various actors in the Kenyan electricity sector as well as the structural, governance and regulatory incentives on utility performance. The aim is to understand how the principal-agent theory, combined with power sector reform theories, provides a more powerful analytical framework to better explain the performances of utilities. Agency theory further helps us to explore the behaviour and incentives accruing to principals and agents [33] as motivation for their actions - using a metaphor of a contract. Bringing these two bodies of theory together provides a potentially powerful analytical framework for comparison and understanding of utility performance.

\section{Analysis and Results}

\subsection{Power Sector Reforms in Kenya}

The figure below shows the key reform components and timeline of reforms in Kenya's power sector.

Figure 2. Kenya's Power Sector Reform Timeline

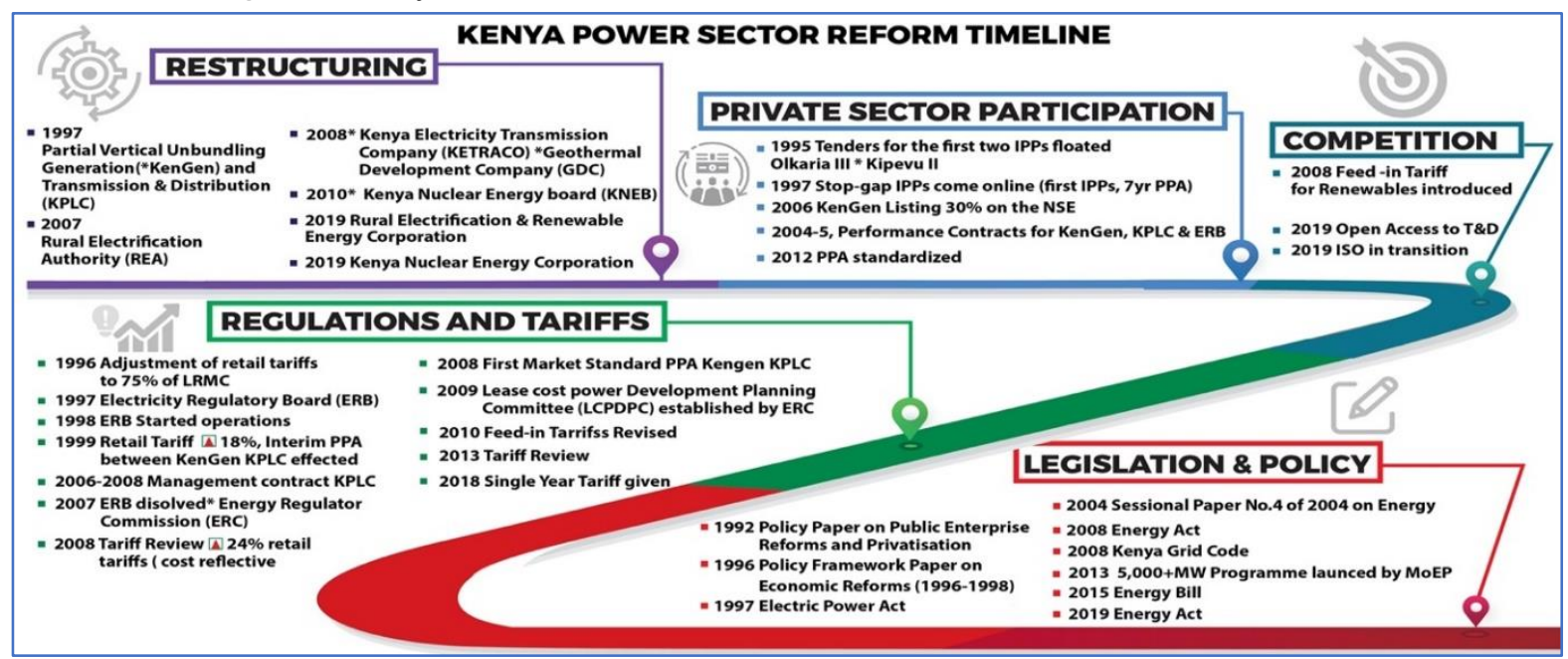

Source: Author's creation

During the period 1990-1994 Kenya experienced major macroeconomic challenges resulting from a confluence of factors, including drought and deterioration in its terms of trade. Donor funding to the power sector was frozen between 1991 and 1996, mainly because of governance failures linked to allegations of corruption. The 1992 policy paper on Public Enterprise Reforms and Privatization was one of the responses during the aid 
embargo. It set the basis for later reforms in the power sector and deregulation of the Kenyan economy that began in 1993 [2]. Over this period the IMF and the World Bank outlined terms for lending that were conditional on reforms, including; tariff studies, reorganization of the power sector, and legal and regulatory reforms. Subsequently, a move towards cost-reflective tariffs ${ }^{3}$ (a component of commercialization) was adopted.

As the country emerged from an aid embargo, one of the state's main objectives was to attract much-needed private sector investment to complement limited public sector investment. In a policy paper on economic reforms at the time (Government of Kenya, 1996), the government outlined its intention to separate the regulatory and commercial functions of the sector, to facilitate restructuring, and to promote private-sector investment, including via IPPs (following the recommendations of the World Bank and the IMF). Meanwhile, the power situation deteriorated further. In the agreement reached at the end of 1996, World Bank funding was made conditional on unbundling the generation segment from KPLC, restructuring, and enacting enabling legislation. Consequently, the Electric Power Act of 1997 was passed [34].

The government's primary function, through the Ministry of Energy and Petroleum (MoEP), became policy formulation, and its regulatory authority was devolved to the newly established Electricity Regulatory Board (ERB) that became functional in 1998. At the industry level, rationalization and unbundling redefined the scope of KPLC, which had operated as an integrated utility since 1954. From 1997, KPLC began to focus exclusively on transmission and distribution, while a separate entity known as KenGen (formerly Kenya Power Company- KPC) took over all public power generation activities.

In addition to restructuring and reorganizing regulatory functions, KPLC, with support of the World Bank and external consultants, began the first competitive process for tendering and negotiating IPP contracts. In 2003, the government expressed dissatisfaction with the performance of the energy sector [35], noting that, despite the reforms, including the introduction of IPPs, electricity in Kenya was still unreliable and expensive. To remedy this, a deeper, second wave of reforms was recommended and subsequently detailed in the national energy policy of 2004, commonly known as Sessional Paper No.4 of 2004 [36], which set the basis for passage of the 2006 Energy Act and outlined the government's commitment to:

- $\quad$ establish a rural electrification authority;

- $\quad$ accelerate the increase in the rural electrification rate by 10 percent a year;

- facilitate the development of a competitive market structure for the generation, distribution, and supply of electricity;

- $\quad$ establish the Geothermal Development Company (GDC) to assess Kenya's geothermal resources, including steam-field appraisal and development;

- $\quad$ establish KETRACO to build new transmission lines using government funds and concessionary financing;

- $\quad$ provide an increase in the lifeline tariff for domestic consumers of up to $50 \mathrm{kWh}$ per month from July 2008;

- $\quad$ enact new legislation to, among other things, dissolve the ERB and create a new independent energy sector regulator - the Energy Regulatory Commission (ERC), and

- partially privatize KenGen through an initial public offering of $30 \%$ of its equity through the Nairobi Stock Exchange.

Unlike the first wave of reforms, which were mainly donor-driven, the second set of reforms was initiated and led locally. By 2007, most of these measures were implemented, including KenGen's listing on the Nairobi Securities Exchange in 2006. Exceptions were the development of a fully competitive market structure and the ambitious rural electrification target [34], [37]. The Energy Act of 2006 provided that the ERC would be funded through not only electricity levies but also fuel levies from downstream petroleum regulation, enhancing its financial independence. In 2008, the Kenya Electricity

\footnotetext{
${ }^{3}$ In 1997, tariffs were increased to $75 \%$ of long-run marginal costs.
} 
Transmission Company Limited (KETRACO) was established to focus on the construction of new transmission projects, facilitated by funding from the government and donors through concessionary financing, while KPLC retained responsibility for operating the grid. KETRACO currently owns over $42 \%$ of the total transmission network and is poised to become the dominant transmission company once the committed transmission projects are completed. The GDC was also established but has been less than successful in its mandate to lower the risks of geothermal development for private sector investment [2].

In 2008, Kenya's Vision 2030 (encompassing social and economic goals) set a new generation target of 23,000 MW by 2030 (up from 1,310 MW in 2008). Rural electrification efforts aimed to bring electricity to every home in Kenya with interim targets set for 2013 and 2022 (these have since been shifted) [34]. In 2010, the government began work on a nuclear power project through the Kenya Nuclear Electricity Board (KNEB), recently reestablished as Nuclear Power and Energy Agency (NPEA) in 2019, an autonomous institution within the MoEP [38]. The initial aim was to generate $1000 \mathrm{MW}$ of nuclear energy by 2023, but by 2019 little progress had been made.

In September 2013, the MoEP launched the '5000+ MW' programme with the goal of bringing at least $5000 \mathrm{MW}$ of power online within 40 months, and IPPs were prioritized to play a central role [39]. The programme was heralded by the Kenyan government as the means to 'transform Kenya', by providing adequate generation capacity at a competitive rate [40]. However, this programme has proven difficult to implement and points to some weaknesses of coordination and planning in Kenya's power sector. In 2017, the government announced plans to halt the programme, citing concerns of depressed demand and expensive loans [41]. Meanwhile, at the generation level, the ERC in 2014 affirmed that 'electricity generation in Kenya is liberalized', with IPPs given an opportunity to enter the sector and compete alongside the state-run KenGen [34]. A competitive market structure has been set in motion with the passing of the Energy Act 2019, providing the legal basis and institutional frameworks to facilitate a competitive wholesale market structure in the country.

\subsubsection{Private Sector Participation}

Private sector participation in generation has been practiced for over two decades in Kenya and its share of installed generation capacity has risen to $36 \%$ by 2020 , contributing about $26 \%$ of production. With the increased IPP commitment and shift to renewables, IPPs are expected to play a significant role into the future. Of the near-term capacity envisioned in the 5,000+ MW program, the majority (70 percent) is expected to come from the private sector with KenGen and GDC developing the balance.

\subsubsection{Progress in Setting up IPPs}

The first wave of privately financed generation dates back to 1996 involving the procurement of two diesel IPPs: Westmont (46 MW) was sponsored by a Malaysian firm, and Iberafrica (44 MW) [1]. With a tenure of seven years - longer than that of most EPPs these first two IPPs were considered stopgap measures for addressing drought-induced hydroelectric shortages and the delayed construction of projects envisioned in the LCPDP. Iberafrica renewed its contract in 2004 and increased its capacity progressively to reach $108 \mathrm{MW}$ in 2015 [1].

The second wave of IPPs - during 1997-99 - occurred amid a move to reform and liberalize the sector. In 1996, KPLC ran international competitive bids (ICBs) for two projects-Olkaria III and Kipevu II - which came to be known as OrPower4 (with varying MW/geothermal) and Tsavo (74 MW/diesel) respectively. Although both projects were procured via ICBs, it is noteworthy that only three bids were received for the Tsavo plant and two for what would become OrPower4 [1]. KPLC subsequently also ran ICBs for the thermal IPPs - Rabai, Thika, Gulf and Triumph - obtaining progressively more competitive prices. Drought conditions and worsening hydrological conditions in the decade 2000-2010 led the MoEP to directly engage three international EPPs (Aggreko, Cummins, and Deutz) for a combined 105 MW rental capacity during 2000-2001. In 2006 Aggreko would be called upon again to provide $80 \mathrm{MW}$ and further increases to $290 \mathrm{MW}$ by 2009. 
In 2012, there were 120 MW of EPPs: to date all these have since been decommissioned. Recently, a number of projects have been procured through a renewable energy feed-in tariff scheme. By end of 2020, Kenya had 17 IPPs with installed capacity of 1,013 MW, thus increasing security of supply.

\subsubsection{Private Management Contract - Manitoba Hydropower}

Reforms also led to Kenya's first private management contract in the power sector. Following a review of tariffs and performance of KPLC that revealed inefficiencies, KPLC was put under a private management contract - which was seen as a means of severing political and bureaucratic influence over utility staff by government officials [2] and was also a condition to unblock US\$152 m from the World Bank, which also set goals to increase connectivity by 200,000 customers and reduce system losses by $14.5 \%$ [42]. Other targets included obligations to improve billing and revenue collections and to improve reliability of supply and technical efficiencies (design and implement N-1 contingency for the transmission system operator).

A two-year contract was awarded to Manitoba Hydro in May 2006 after a competitive tender. The contractor provided a 3-member senior management team comprised of the $\mathrm{CEO}$, finance, administration and technical experts and all other departments were realigned and merged to report to the three functional heads. Worth noting is that the new management did not terminate any of the existing staff but focused on training and coaching local staff to improve work culture. The contract continued the positive trends of reducing system losses and improving collection rates, with the latter reaching close to $100 \%$, while losses decreased further to $16.6 \%$ in 2008 .

At the same time, profits increased, and a healthy debt-service coverage ratio was maintained. The utility increased in new customers by 258,134 in two years from the previous 40,000 per annum. The contractors also introduced preventive 'live-lines maintenance' without switching off power, which greatly improved reliability. In 2008, government decided not to renew the contract citing the realization of the set objectives for contractors. Other stakeholders interviewed, however, pointed to the tension and conflicts that arose in 2007 (at the onset of a drought) between the MoEP and contractors, regarding direct procurement of IPPs and EPPs desired by government, which the contractors rejected. Others cited the anomaly of government continuing to provide subsidies to KPLC while the contractors were promising financial viability, and the fear of possible staff retrenchments. Though the management team was not well-liked by local KPLC staff, the two-year period allowed them to build internal capacity and a greater degree of independence from political influence, as well as a sense of purpose and ownership over the new trajectory of power sector reform and development in Kenya. As part of its exit strategy, Manitoba Hydro partnered with KPLC to form Kenya Power International -an offshoot of KPLC that provides consulting services across Africa and the Middle East.

\subsection{Governance Framework and Structure in Kenya Power (KPLC)}

KPLC's governance is framed by key legislation and policies, including the Companies Act 2015 Cap. 486, the Capital Markets Act 2012 Cap. 485A, the State Corporation Act 2012 Cap. 446, the Code of Governance for State Corporations (Mwongozo), and the Board Charter, all of which outline the structure, composition, roles, responsibilities and functions of the company, the board and committees. KPLC is a listed company with $49.9 \%$ of its shares ${ }^{4}$ publicly traded on the Nairobi Securities Exchange and the remaining 50.1\% owned by the government of Kenya. This capital structure makes it a mixed capital enterprise (MCE), thereby creating new principal-agency relationships. For this reason, the company is also obligated to comply with the Code of Corporate Governance Practices for Issuers of Securities to the Public 2015, and the Capital Markets (Securities, Public Offers, Listing and Disclosure) Regulations, 2002.

The corporatization reform and streamlining of board composition to include independent directors is meant to check excesses of government-sanctioned political influence

\footnotetext{
${ }^{4}$ Most of these are owned by institutional investors (banks) and local individual investors.
} 
as well as to protect the interests of private shareholders (principals), without which the company risks permeation of rent-seeking moral hazards.

In addition, the BODs, as an internal control mechanism of agency problems, helps to monitor and evaluate the performance of top management. It helps shareholders to control possible information asymmetry, management perquisite consumption ${ }^{5}$ and entrenchment ${ }^{6}$ - traditional agency problems that affect performance.

However, since private shareholding is thinly and widely spread, with no large-block stockholders, in practice "there has been minimal-to-no representation of private sector interests on the board" as intimated in one of the interviews. "The government as majority shareholder, has a firm grip on the board." Continued government influence adversely affects post-privatization company performance.

\subsubsection{Board Structure and Functionality}

As a partially privatized company, the board is structured to have a diversity of skills which allows for exposure to a market-oriented competitive environment, thereby enhancing KPLC performance - unlike traditional SOEs which may have good technical skills but lacks many essential skills to compete in a free-market economy. The creation of two board committees: strategy, and the communications and technology and power purchase agreements (ICT\&PPA) committee, reveals the importance the board attaches to KPLC's performance and energy security as priorities. Typically, KPLC board members are incentivized with; directors fees of Ksh600,000 annually or, on pro-rata basis for the period served; a sitting allowance of Ksh20,000; telephone allowance of Ksh20,000; a lunch allowance of Ksh2,000 per sitting; accommodation allowance for work-related trips; mileage allowance, and training fees. The board chairman receives an additional honoraria of Ksh80,000 per month. These incentives provide motivation for the board's supervision of management to improve KPLC's performance.

\subsubsection{Mwongozo (The Code of Governance for State-owned Corporations)}

The Mwongozo ${ }^{7}$ [43] was born out of the realization that state-owned enterprises (SOEs) had, over the years, and with new challenges, not operated at expected levels owing to weak governance structures and poor leadership in the management of public resources. The code has been adopted as a state-motivated reform to create a transformational mindset in the way business is conducted to increase efficiency and accountability in the use and deployment of scarce resources. One of the governance challenges faced by SOEs is insufficient competence in boards of SOEs, as well as embedded political interests, arising from an opaque appointment process. A professional and independent board is more likely to safeguard an SOE from political interference, lead to more efficient operations through well-defined strategy and could ultimately result in increased value-formoney to the shareholders. The Code of Governance, in relation to Kenya and KPLC, provides a framework for improving corporate governance by allowing for the appointment of professional boards with well-defined skill sets; the undertaking of board inductions and evaluations, and requires regular performance reports. The Code has also provided for reform and reduction in the size of the boards and the increase in the number of independent board members to reduce conflicts of interest, which is a game-changer in boardroom affairs. It further provides a platform for addressing shareholder rights and obligations with the aim of ensuring that sustainable performance excellence become the hallmark of SOEs.

\footnotetext{
5 Short-term cost-augmenting activities by managers designed to enhance non-salary income or provide other on-the-job consumption

${ }^{6}$ Refers to actions of management that reduce the effectiveness of control mechanisms designed to regulate management behaviors

7 Swahili for Guide or Regulations was developed in 2014 and is anchored in the Constitution of Kenya, 2010 Articles 10, 73 and 232 that espouse national values and principles of good governance -integrity, efficiency, and effectiveness, and carries the same legislative importance.
} 
Drawing from its past aid embargo experience and the desire to exploit energy resources to spur growth in the economy, the government implemented the Mwongozo to streamline governance and to attract investments. Despite the previous caveats around ongoing political interference in KPLC's board, the Mwongozo code is a positive reform initiative to inculcate good governance principles in all SOEs. It promotes greater autonomy, transparency, accountability and leadership focused on performance, for the purpose of improving service delivery unlike in other countries in the region. This initiative has also created a better investment climate and gives greater regulatory certainty, which has catalyzed growth of IPPs as well as greater certainty of shareholder investments in KPLC.

\subsubsection{Accountability, Transparency, Disclosure, Risk Management, and Internal Con- trol}

While KPLC maintained a strong financial performance for many years, in recent times its solvency has declined and, as such, the Auditor General noted a breach of commercial borrowing covenants in 2018 by Ksh59.9 billion ${ }^{8}$. Although lenders waived their rights to demand payment owing to breach of debt covenants, it signals increasing financial stress ${ }^{9}$. This breach also means that the company violated the capital markets ${ }^{10}$ listing obligations in regard to maximum debt capacity and solvency ${ }^{11}$ [3, pp. 112-117].

In July 2020, the board of KPLC was forced to resign for failure to disclose to government the magnitude of financial distress resulting from an inadequate tariff review, excessive debt levels and high operating costs associated with the access and network expansion program, overcommitment in new IPPs (the 5,000+ MW program), and financial mismanagement in operations, threatening the financial sustainability of the company [8], [44]. In sum, the intervention of the auditor-general and penalties by the CMA underscore the strength of the independent governance system in Kenya and in KPLC, occasioned by corporatization and privatization reforms.

\subsubsection{The Capital Markets Governance, Listing Rules and Regulations}

KPLC's Listing on the main investment market alters governance arrangements by introducing new and wider stakeholders - such as customers, the public, the media, investors, and other market participants, unlike in traditional SOE governance structures. A strong discipline of private capital is introduced through stock listings and bonds by increasing the levels of scrutiny on governance and management processes. One such discipline is for listed companies appointing a person who is a certified director from an institution recognized by the CMA. This standard has the potential to eliminate would-be incompetent political appointees in SOEs and reduces conflict of interest by government, since qualification requirements are pre-defined by an independent institution. In addition, the capital markets regulations introduce an element of penalty, liability and sanctions to the company, or any company director, or management staff (jointly or severally) who contravenes the set regulations - legal effect.

The CMA also provides for potential suspension and delisting of the company. This incentive mechanism compels directors and management to strive for improved performance. Related to this are requirements to improve financial performance, pursuant to the listing and disclosures regulations [45] - the performance effect. Specifically, the First Schedule of the Capital Markets (Securities) (Public Offers, Listing and Disclosure) Regulations, 2002 (Amended 2016) sets out minimum requirements for listing and continuing obligations of the listed entity to have a clear future dividend policy and a track record of

\footnotetext{
8 KPLC's total borrowing as at end of 2018 amounted to Ksh 113 billion.

9 In July 2018, majority of KPLC senior management were arrested and charged at the High Court with alleged corruption relating to procurement violations and material misstatement of financials (information asymmetry) and subsequently terminated.

10 Although CMA imposed penalties as confirmed from interviews, these were not publicly disclosed.

11 At the end of 2018, the company's current assets of Ksh 54.6 billion were less than current liabilities of Ksh 106.3 billion, resulting in a negative working capital of Ksh 51.6 billion.
} 
profitability and future prospects - including adequacy of working capital [46]. It also sets as a mandatory requirement for the company not to be in breach of any of its loan covenants, particularly regarding the maximum debt capacity.

The accounting effect is that the existence of strong accounting standards does improve the investment performance and climate of a company as far as shareholders are concerned. Therefore, the CMA and financiers require that an external audit is done on the financial covenants every year in accordance with IFRS and before publication of results in the main media outlets.

\subsection{Electricity / Energy Regulation and Regulatory Regime}

Since its establishment as an electricity regulator in 1998, and then as an energy regulator in 2007, ERC/EPRA as a principal has played a crucial role in balancing decisionmaking in the sector, especially between privately owned IPPs and the publicly owned generation company KenGen. The ERC/EPRA has licensed new capacity, creating security of supply and approving near-cost-reflective tariffs for KPLC. However, recent involvements by government in sector regulation and planning is undermining regulatory independence and effectiveness in regulating market entry, tariff reviews and system planning.

Following an earlier pronouncement by President Uhuru in 2016 to reduce the cost of power [47], a task force team was formed, headed by the Ministry of Energy, to review all existing PPAs; to establish revenue requirements for each; to explore possibilities for mutual termination (or compensation payments for termination), and to compare PPA costs with similar plants regionally and globally [48]. The major recommendations among 10 others are: (i) that existing PPAs should be renegotiated; (ii) pipeline/unconcluded PPAs should be cancelled; (iii) the cost of electricity be reduced by $33 \%$; and (iv) restructuring KPLC into a commercial entity that is both profitable and providing cost effective electricity [49]. There is no clear pathway how the regulator will implement these recommendations without ensuing legal suits.

In addition, in a bid to implement government's recent policies geared towards industrialization and employment, the regulator has been directed to heed policy and not to increase tariffs. Government's emphatic argument as intimated in interviews has been that "the law/regulation follows policy and hence any inconsistencies in it are an area for law reform and not the reverse". Specifically, the EPRA has been pressured to set low tariffs that reflect policy objectives rather than economically efficient prices. The regulator has also been accused of an inability to stand firm in exercising its legal mandate to determine cost-reflective tariffs, owing to fear of job termination. Government has seized this weakness to push for a move away from cost-reflective tariffs towards more subsidies, in the hope of stimulating employment [47], [49]. This signals a potential decline in the role of the regulator and the energy sector.

\subsection{Analysis and findings: Operational Performance of KPLC}

An empirical and analytical analysis of the operational performance of KPLC, considering five key performance measures which mirror the enduring challenges facing utilities: access to electricity; adequate and reliable supply; efficiency; affordability, and financial sustainability is presented below.

\subsubsection{Access and Electrification}

Kenya is implementing an aggressive electrification programme that has more than doubled the number of grid connections in a span of just five years with the aim of achieving universal access to electricity by 2022. KPLC has connected, on average, about a million new customers annually during the last four years (2014-2018) and had about 6.7 
million customers as of June 2018 ${ }^{12}$. About $65 \%$ of these new connections are in poor households which consume less than $15 \mathrm{kWh}$ monthly[50], [51]. The government has developed programmes of subsidizing connection costs through budget transfers of about US\$ 700 million. Under the LMCP, households pay a reduced connection cost of Ksh 15,000 (US\$150), and the Government subsidizes the rest. An innovative output-based mechanism (OBA) was adopted for slum electrification.

As a result, national electrification rates are currently $75 \%$ (84\% of urban and $71 \%$ rural) [52]. However, in a bid to meet the LMCP targets, KPLC has also had to divert resources to access-related infrastructure, and these amounts swelled over time as the utility tried to connect people living farther away from the grid. Billings too (consumption and net revenue per customer) and loss reduction have deteriorated [50]. The Last Mile programme obliged the government to reimburse KPLC for maintenance and connection costs, but the transfers have been insufficient to avoid significant adverse financial impact on the utility.

It is worth noting that the early structural reforms of the sector did not materially impact the pace of electrification and it was necessary for the government to adopt additional and more ambitious targets for universal access, backed by dedicated financing and donor support, without which access rates would have remained low. In addition, regulatory reforms in early the 2000s have created a strong enabling framework for growth of off-grid electrification efforts in Kenya as a leader in access in the region.

Figure 3. Number of Connections to the Grid

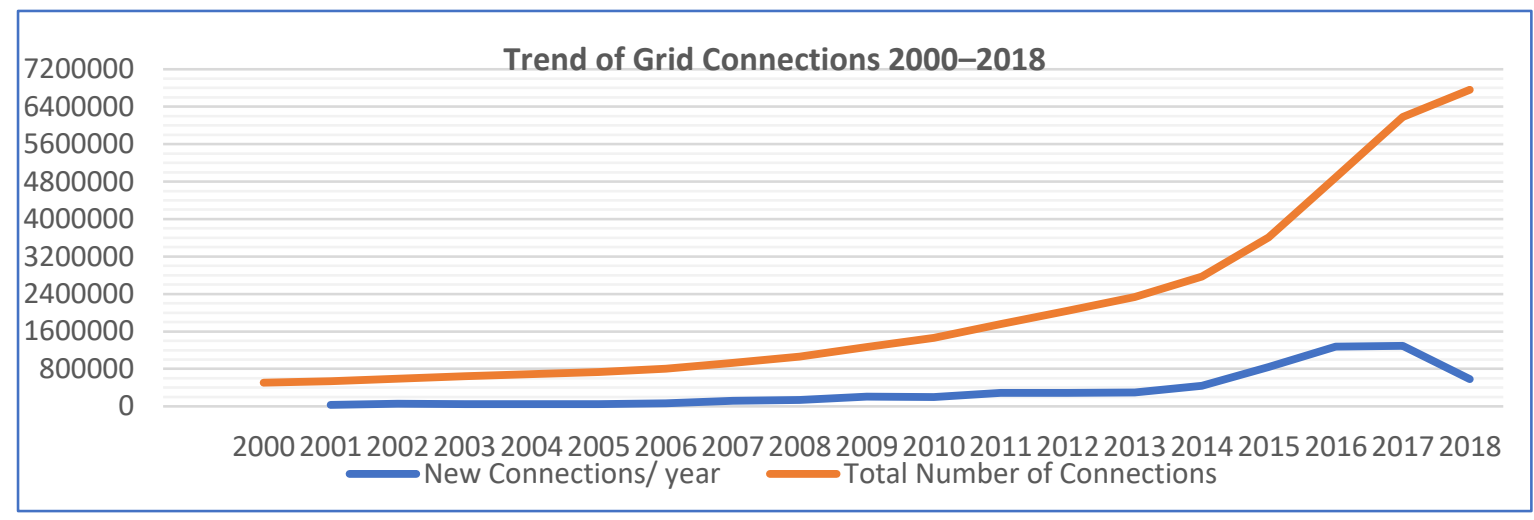

There is a broad lesson here. Progress in electrification requires national goals and targets, planning and subsidies for connections. However, as more and more low-income households are connected, especially in deep rural areas, the issue of affordability arises (which is examined later). Likewise, consumption remains low and is generally insufficient to either pay for grid strengthening and extensions, or the operating and maintenance costs of these services. It shall be shown, how this has impacted KPLC's financial performance. For high levels of electrification to be sustainable, some level of cross subsidies is generally required for low-income households.

\subsubsection{Adequate and Reliable Electricity Supply}

Over the past two decades, Kenya has been one of the most successful countries, a leader in Africa, in taking bold steps towards enhancing security of supply. In particular, since 1990, net generation capacity has more than tripled to reach a current level of just over 2.8 gigawatts $(\mathrm{GW})$. Kenya has also diversified its power system from reliance on almost exclusively hydro-electricity to a more balanced mix of hydropower, geothermal

12 This performance exceeds what South Africa achieved at the height of its electrification programme - less than 500,000 connections per annum - but still one of Africa's most successful efforts, raising access rates from about 50\% in 1994 to close to $90 \%$ today. 
and oil-fueled generation, and, in recent years, also wind and solar energy. Kenya's previous reliance on hydropower led to repetitive supply crises in the 1980s and 1990s. With the aid embargo, and unable to access funding for new generation capacity, the country faced severe supply constraints resulting in contracting of expensive emergency thermal power, which, in turn, increased the cost of supply as it waited for the commissioning of the state-owned and IPP plants. The country revised its approach to generation planning and adopted reforms to attract private-sector investments into the sector. Following the unbundling of generation from transmission and distribution, a new and better coordinated planning and procurement system ushered in a series of IPPs worth over US\$3.0 billion. The increased capacity translates into improved reliability of supply.

Figure 4. Trend of Growth in Installed Generation Capacity (MW)

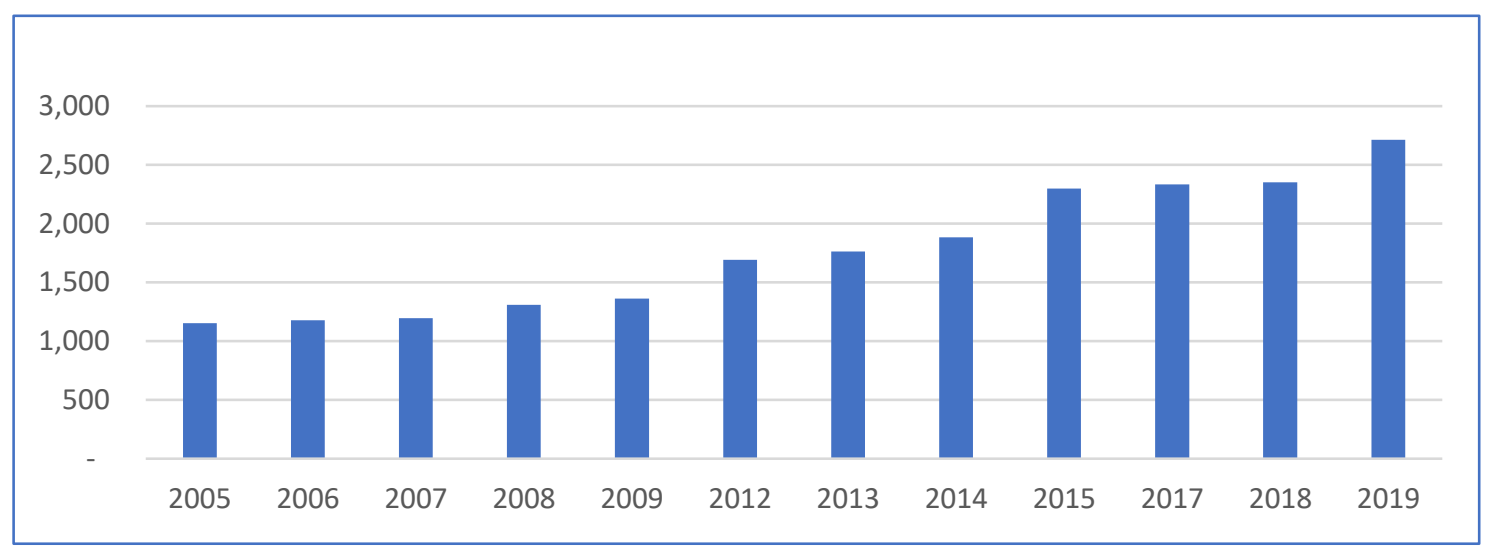

Figure 5. Installed Generation Capacity by Energy Source

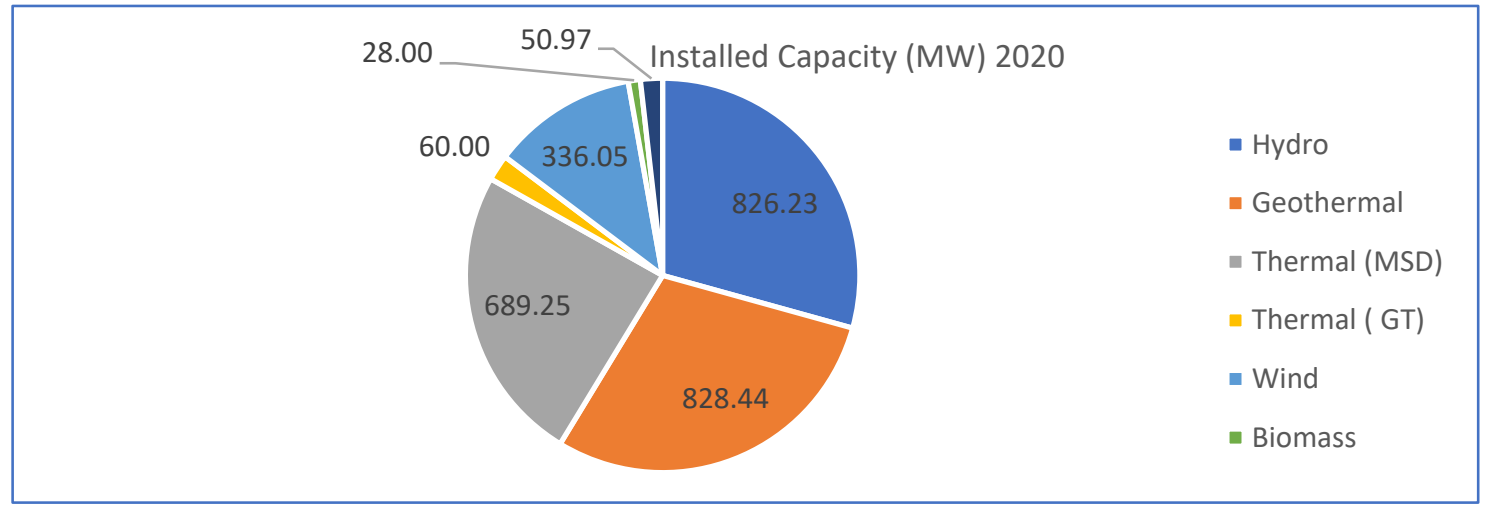

Source: Author's creation based on KPLC primary data

\subsubsection{Generation Mix}

Kenya's security of supply has improved through marked diversification of the energy mix. With restructuring, the country sought to de-risk geothermal resources managed by a corporatized GDC. Currently, geothermal capacity is $828 \mathrm{MW}$ contributing $44 \%$ of electricity production, and this share has been growing since 2014, helping to displace the more expensive thermal generators. Following the commissioning in 2015 of the latest large geothermal plant of $280 \mathrm{MW}$ at Olkaria, consumers saw a reduction in fuel costs. The share of hydro has declined from above 50\% in 2012 to about 33\% today. The recent (2019) commissioning of the Lake Turkana Wind Project - 310MW, has increased the contribution of wind to $10 \%$ and was projected to increase to about $12 \%$ beyond 2020 . Overall, there is a shift towards more renewables whose share is now amongst the highest in the world. 
Figure 6. Trend of Kenya's Generation Mix (MWh)

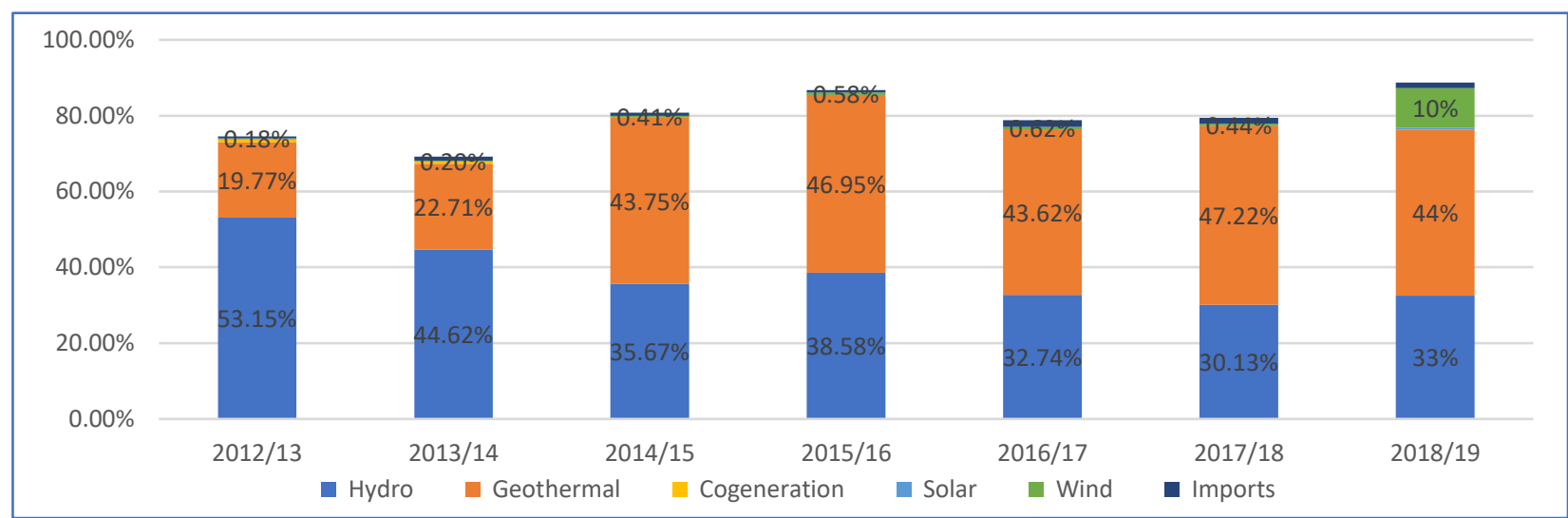

Source: Author's creation based on KPLC primary data

\subsubsection{Reliability of Supply}

Despite having surplus generation capacity, it has not always translated into improved reliability of supply for customers, mainly because of deficiencies in the transmission and distribution segment. The transmission and distribution network is currently overloaded due to the aggressive electrification and significant under-investments as dependence on government budget allocations for capital expenditure and for right-of waycompensation (wayleaves) in a tight fiscal environment means budgetary transfers are inadequate and frequently delayed, resulting in KETRACO being unable to complete projects on time, or for KPLC to properly maintain the grid for reliability. Despite these challenges, KPLC performs better on this reliability index than sister utilities in the region.

Figure 7. Performance of CAIDI(hrs)

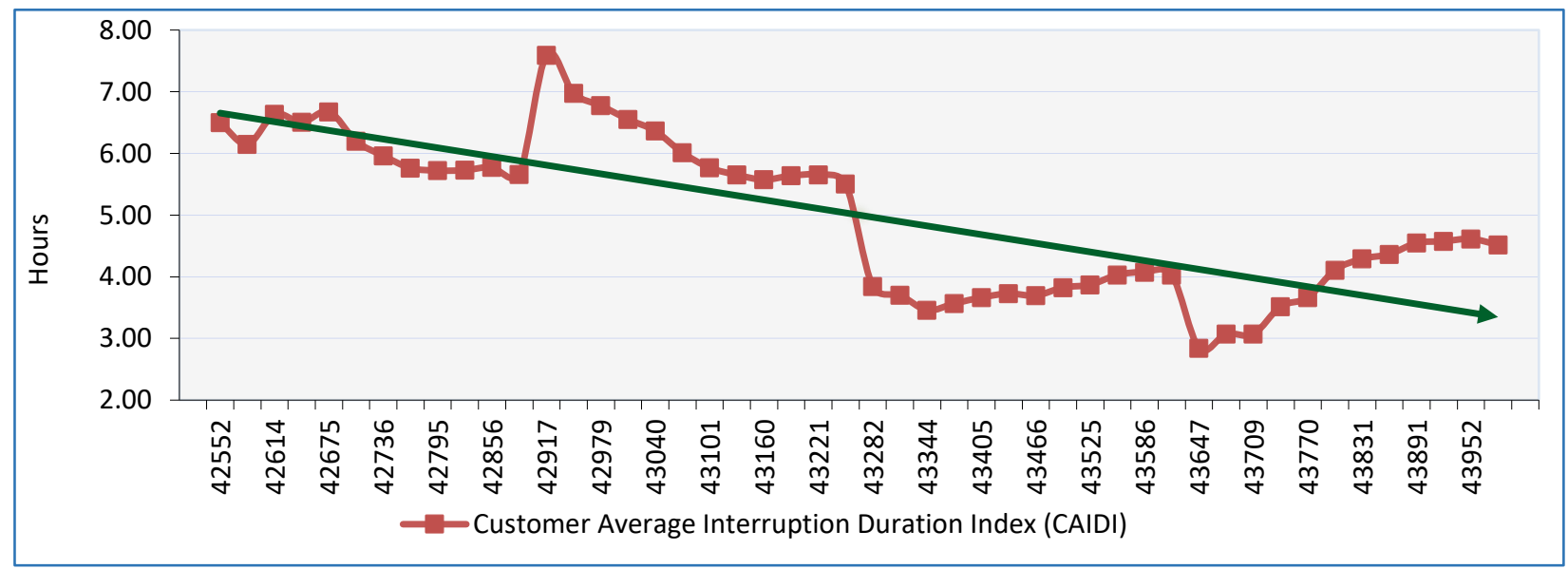


Figure 8. Performance of SAIFI (no.per month)

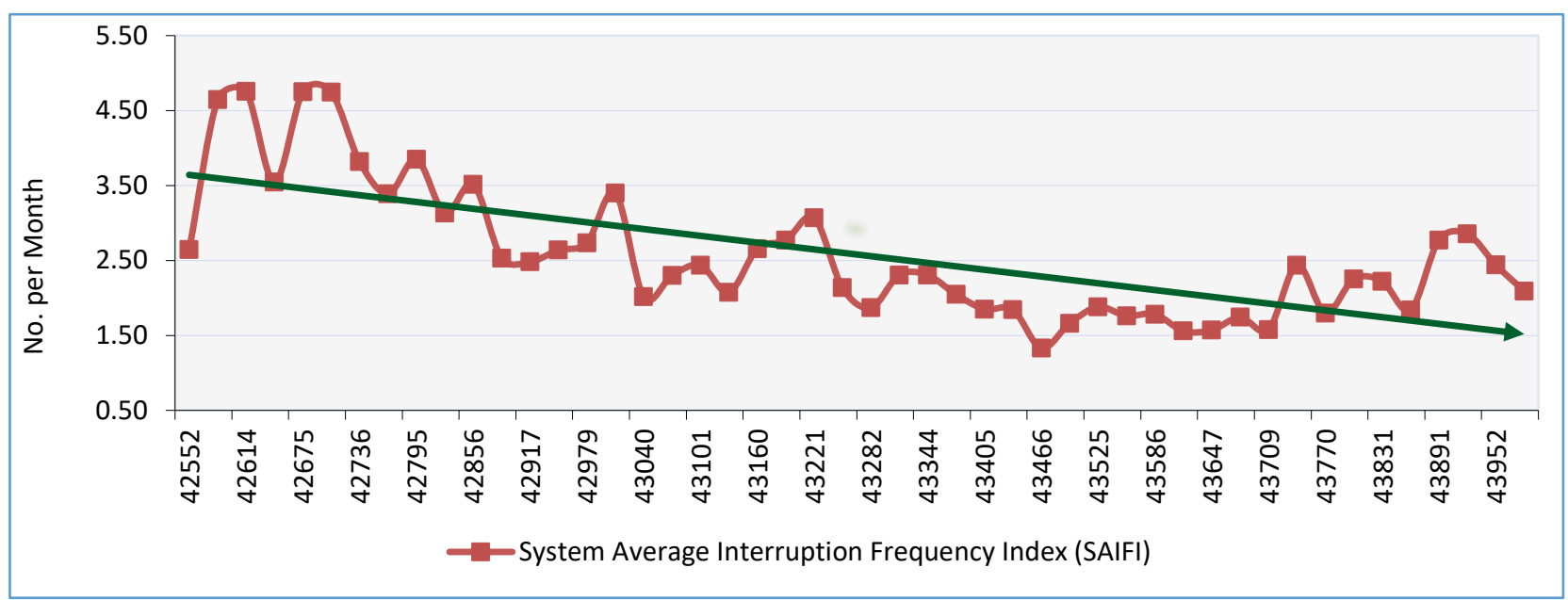

Source: Author's creation based on KPLC primary data

\subsubsection{Affordability}

Despite the relatively high cost of electricity in Kenya, the cost of a subsistence volume of 30 kilowatt-hours per month is well under $5 \%$ of the budget of the poorest $40 \%$ of households [53]. Electricity appears to be affordable with lifeline tariffs (Ksh 10 for 100 $\mathrm{kWh}$ ) and subsidized connection charges. However, electricity consumption has not risen as sharply as the number of connections.

Figure 9. Average Tariff $(\$ / \mathrm{kWh})$ trend

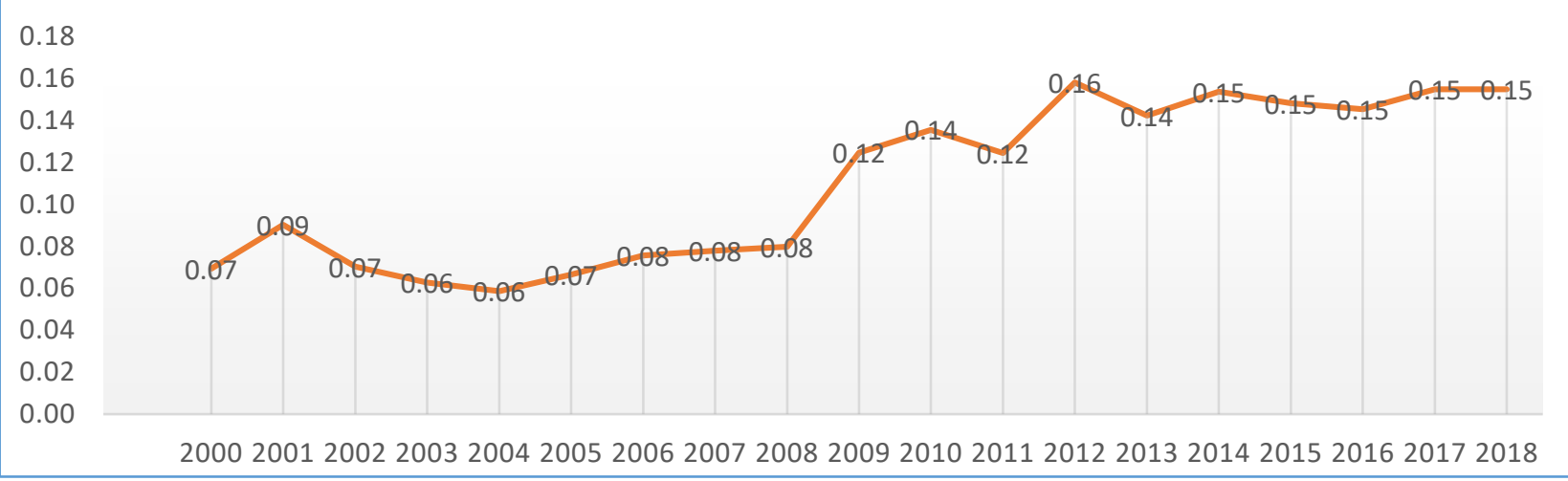

Source: Author's creation based on KPLC and EPRA data

While the regulator is meant to conduct a tariff review every three years, only four reviews have been carried out - 1999, 2008, 2013 and 2018. In 2018, a single-year review was granted rather than the prescribed multi-year tariff and no further review has been conducted since.

Although reforms led to the establishment of an independent regulator, regulatory independence in tariff determination is increasingly eroded as the government influences tariff decision-making to achieve political goals. Often under the pressure of elections, government has halted the automatic tariff-adjustment and review mechanisms. A top manager in an interview decried this as: " ...the regulator is heavily influenced by government - doesn't provide adequate revenue requirements which threatens the commercial viability of KPLC". Another respondent had this to say "ERC/EPRA as a principal is facilitating the financial collapse of KPLC". Hence, in a weakened institutional 
governance setting, governments are able to influence pricing decisions even under partial post-privatization conditions.

\subsubsection{Efficiency}

For this paper, efficiency is assessed in a limited way using two KPIs - system losses and revenue collection rates. Following the resolution of the tariff imbalance between KPLC and KenGen, the KPLC was put on a performance contract in 2004 and KenGen in 2005. The PC, as a new governance-monitoring tool, had an immediate impact on collection rates, which increased to almost $99 \%$ in 2005 from $81 \%$, and transmission and distribution losses reduced to $18 \%$. The introduction of a private management contract in 2006 (Manitoba Hydro) helped to push collection rates to $100 \%$ and technical losses declined to $17 \%$ by end of the contract in 2008 . The recent connectivity drive for universal access, however, has dented this stellar performance as collection rates have declined to $98 \%$ and losses have risen to highs of $21 \%$ largely due to non-payment of bills and power theft [3], [7]. While reforms such as the management contract enabled greater efficiency improvements, these benefits are being eroded by governance weaknesses associated with government influence. It remains to be seen whether KPLC will recover from this recent decline.

Table 1. Trend of Revenue Collections and Losses

\begin{tabular}{|c|c|c|}
\hline Year & $\begin{array}{l}\text { Collection } \\
\text { Rate: } \%\end{array}$ & $\begin{array}{l}\text { Distribution } \\
\text { Losses: } \%\end{array}$ \\
\hline 1997 & & 21 \\
\hline 1998 & & 20 \\
\hline 1999 & & 22 \\
\hline 2000 & & 22 \\
\hline 2001 & 85 & 21 \\
\hline 2002 & 84 & 23 \\
\hline 2003 & 83 & 21 \\
\hline 2004 & 81 & 18 \\
\hline 2005 & 99 & 18 \\
\hline 2006 & 99 & 20 \\
\hline 2007 & 100 & 18 \\
\hline
\end{tabular}

\begin{tabular}{|l|c|c|}
\hline Year & $\begin{array}{l}\text { Collection } \\
\text { Rate: } \%\end{array}$ & $\begin{array}{l}\text { Distribution } \\
\text { Losses: \% }\end{array}$ \\
\hline 2008 & 100 & 17 \\
\hline 2009 & 101 & 16 \\
\hline 2010 & 101 & 16 \\
\hline 2011 & 101 & 16 \\
\hline 2012 & 100 & 17 \\
\hline 2013 & 100 & 19 \\
\hline 2014 & 100 & 18 \\
\hline 2015 & 98 & 18 \\
\hline 2016 & 98 & 19 \\
\hline 2017 & 98 & 19 \\
\hline 2018 & 98 & 21 \\
\hline
\end{tabular}

\subsubsection{Financial Sustainability}

One of the primary drivers of power sector reforms was the desire to im-prove the financial performance of utilities to achieve financial viability and sustainability, and to shift away from state-subsidies, thereby easing the financial burden imposed on the national treasury, while releasing scarce re-sources to other sectors of the economy. 


\subsubsection{KPLC's Financial Performance}




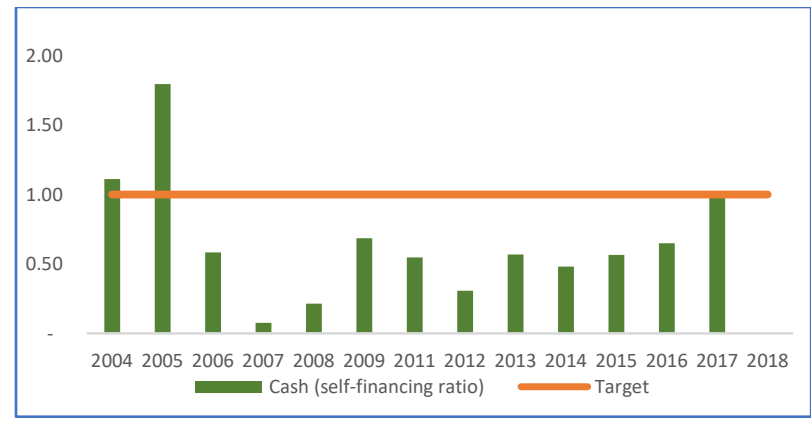

Figure.15. Current Ratio

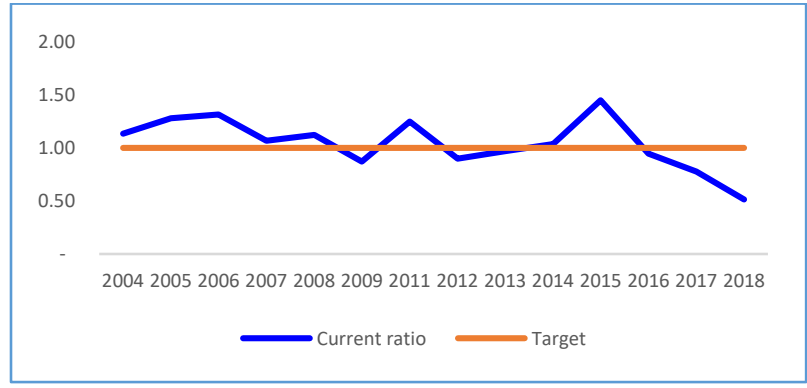

Figure 16.: Interest Coverage Ratio

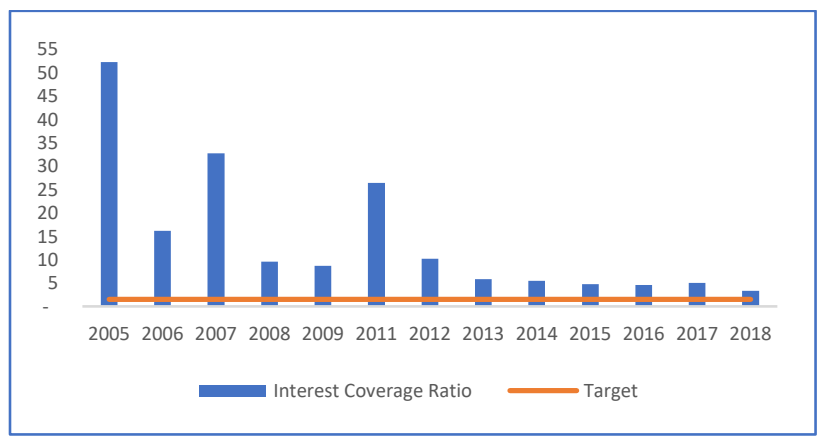

Figure 17. Acid Test (liquidity ratio)

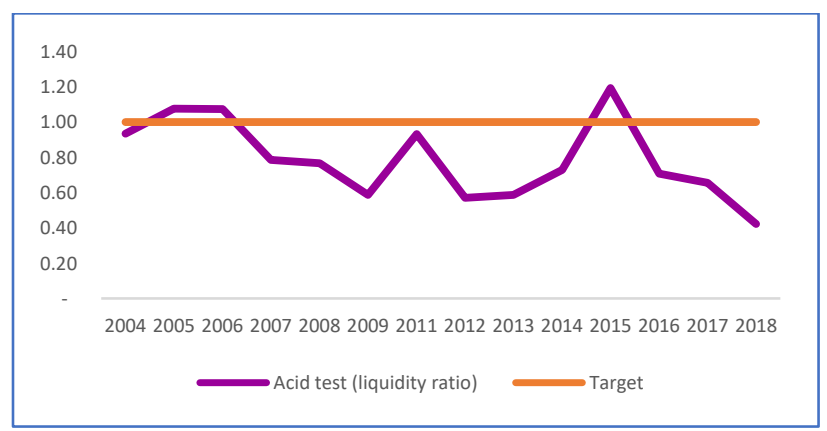

Figure 10.Revenue Growth (Ksh millions)

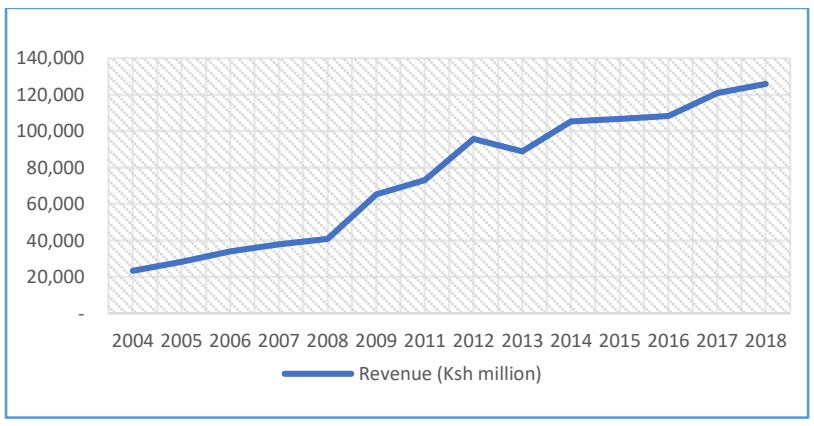

Figure 11: Gross and Net Profit Margins 2004-2008

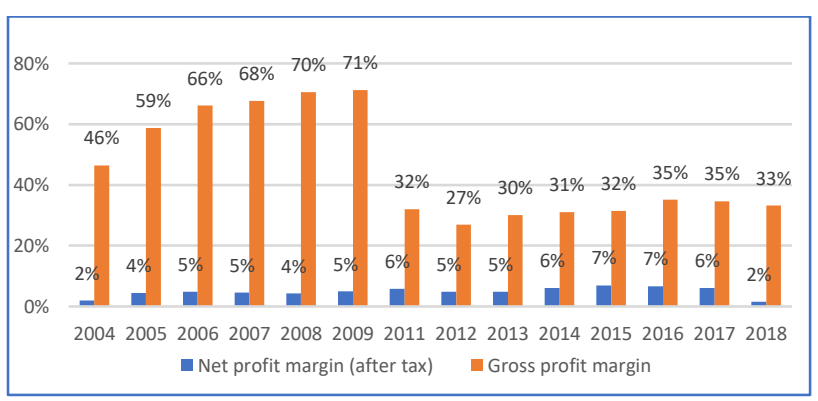

Figure 12.: KPLC Debt-Service Coverage Ratios

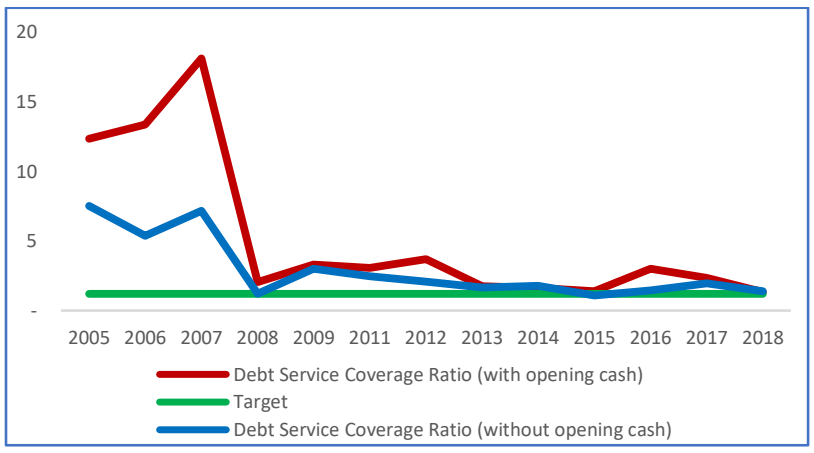

Figure 13: Debt to Equity Ratio

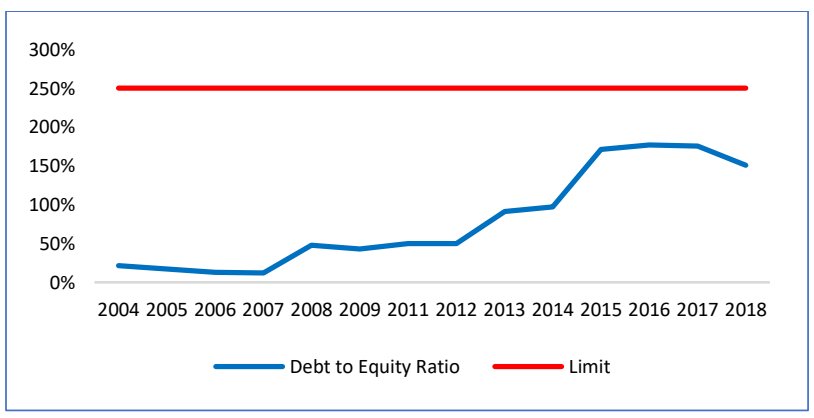

Figure 14. Cash (self-financing) Ratio 
Gross revenues grew from Ksh 23 trillion in 2004 to Ksh 126 trillion by 2018, representing an average growth rate of $10 \%$ per annum over the 14 -year period. However, with the implementation of the Last Mile Connectivity Programme and the connection of more low-demand customers to the grid, the average consumption per customer reduced by an average of $15 \%$ per annum over the period. As a result, net consumer revenues from both industrial (anchors) and domestic customers declined owing to the rise in: cheaper captive and reliable renewables sources, such as solar PV, and power thefts respectively [54]. Nevertheless, regulatory reform that enabled tariff increases has contributed to revenue growth, with the most impactful tariff increases occurring in 2008 by $24 \%$, as well as in 2011 and 2013.

However, the net profit margin declined to $2 \%$ in 2018 owing to a delayed review of retail electricity tariffs ${ }^{13}$, increased operating costs associated with the access programs, delayed fuel cost recoveries, increasing financing costs and doubtful electricity receivables, which negatively impacted cashflows. In nominal terms, profits reduced by $92 \%$ from US\$49 million in 2018 to US\$3 million in 2019 [3].

Recently, KPLC has issued three profit warnings (cautionary earnings statements 2018,2019 and 2020) to its shareholders, citing depressed economic activity and demand, inadequate tariff reviews and increasing financing costs [55]. In order to reverse and stabilize its financial position, the company has sought external debt relief in the form of a 12-month moratorium on its foreign currency-denominated loans and is in talks with local banks to reschedule its multibillion-shilling debt (Ksh 68 billion), which has seen its profitability dip to the lowest in 16 years [56].

The solvency ratios - debt-service coverage ratio, debt-to-equity ratio, and interest coverage ratio - have been positive but there is a declining trend. The company obtained additional facilities ${ }^{14}$ in 2015 that increased its debt by $87 \%$ year on year. This led to a $39 \%$ drop in the DSCR to 1.08, which was marginally below the target of 1.2. In the same year, the company breached its loan covenants and was vulnerable. Further, recent declines in cash flows have made it susceptible to default, unable to service its debt and seeking waivers from its lenders [56]. To date, KPLC's total debt is estimated at US\$1 billion.

An analysis of the liquidity ratios - cash (self-financing ratio), current ratio and acidtest ratio - shows a declining trend in performance, the increasing financial risk of the company and is unsustainable.

This analysis demonstrates that while partially privatized utilities, such as KPLC, are able to perform better than state-owned utilities, if they still have a majority government shareholding, financial governance systems may be vulnerable to being undermined by governments.

\section{Discussions and Limitations}

At a policy level, Sessional Paper No. 4 of 2004, laid a firm foundation for legal and institutional reform of the power sector in Kenya. The policy and new legislation facilitated restructuring of the power market and unbundling of KenGen from the vertically integrated KPLC to: enable a competitive power market for generation, distribution and supply of electricity; the introduction of a lifeline tariff for domestic customers of $50 \mathrm{kWh}$ per month; the partial privatization of KenGen through an IPO offering $30 \%$ stock to the public; and the creation of other corporatized institutions (namely, KETRACO, GDC and REA/REREC) as agents of government that have since also impacted the performance of KPLC in various ways. The corporatization and commercialization reforms allowed for

\footnotetext{
13 The 2013 schedule of tariffs was for a 3-year period with a new tariff expected from June 2016, but this did not happen. Considering that the average revenue requirement, which drives the tariff computation, takes into account the total transmission and distribution assets, failure to review and issue a cost reflective tariff meant that the revenue requirements for 2017-2019 was based on the size of the grid assets as at 2013 and did not take into account the significant expansion of the network in the preceding period, thereby creating a huge financial viability gap for KPLC.

${ }^{14}$ KPLC acquired a long-term syndicated loan of Ksh 50 billion from The World Bank, AFD, Standard Chartered Bank and Rand Merchant Bank
} 
the transfer of authority and risk allocation from the government (principal) to the more technically competent management teams of agents in these entities (with separate governance systems), enabling them to operate on a commercial basis including moving towards cost recovery pricing.

For a long time, Kenya has had a robust planning system buttressed by optimal LCPDPs designed by KPLC expertise, and well linked to procurement of new generation capacity. However, increasing government influence in planning activities in recent years has resulted in the proliferation of directly negotiated power procurements poorly aligned with LCPDP leading to excess supply and costly power for consumers. Thus, in a partially privatized utility, where the power off-taker is government-owned, planning choices are likely to be unduly influenced by political considerations and these can undermine utility performance.

From a governance perspective, commercialization reforms - which introduced performance contracts (PC) between KPLC and the government - have since 2004 helped in monitoring the performance of the board and managers of the company. The PCs, as behaviour-based contracts, provide for targets against which management is assessed biannually by the principals - creating constant pressure to improve performance. In addition, the PCs, as a monitoring and information system, help to reveal agent behavior and serve to limit information asymmetry, moral hazards, agent opportunism, entrenchment and perquisite consumption. Unfortunately, the PCs have been undermined by government and do not provide incentives for staff as prime drivers of performance - an issue that needs to be addressed.

An examination of the different aspects of performance, and commencing with the imperative of access, reveals that the GoK has driven the access and electrification development goal, through an aggressive campaign, to levels higher than in any other country in the region. However, this ambitious programme is now threatening the financial sustainability of KPLC. Government's failure to reimburse KPLC fully for electrification costs underscores a failing principal-agent relationship. Consequently, the principal's continued interference has adversely affected KPLC's liquidity ratios to the extent that the utility has violated its debt covenants. Thus, again, even though KPLC has been partially privatized, its financial governance controls have been undermined, enabled by government's ongoing majority shareholding.

How have the reforms impacted Kenya delivering an adequate and reliable power supply? The unbundling of KenGen from KPLC created an autonomous agent (KenGen) - with delegated authority to procure and contract new publicly funded generation capacity as well as opening the market for IPPs. The rebalancing of tariffs in the early 2000s helped to create bankable balance sheets for KenGen and KPLC, allowing them to attract private investment in generation on commercial terms and ensuring security of supply. The unbundling has also removed potential conflict of interest between KPLC, KenGen and IPPs in the procurement and dispatch of new capacity.

Regarding tariff affordability and cost reflectivity, regulatory reforms established the regulator and has since 2007 played a crucial role in balancing decision-making in the sector, especially between IPPs and the publicly owned KenGen. This has helped to remove potential conflicts of interest, especially in licensing new capacity. Unlike in previous periods when regulatory independence in tariff-setting was respected by all stakeholders, recent involvements by the government/principal in issuing directives, including to halt or postpone tariff reviews, have caused a decline in profitability and financial performance of KPLC and have undermined regulatory independence.

Until 2018, KPLC maintained a healthy financial performance record enhanced by the securities exchange listing obligations and tariff increases. However, in recent years, its financial state has declined significantly. The reversal of the 2017 tariff review had a direct, negative impact on the company's revenues. The company fundamentals have fluctuated with significant declines to below minimum thresholds, indicating the financial vulnerability of the company occasioned by the government's and the regulator's failure to implement cost-reflective tariffs. 
From a capital structure perspective, the listing of KPLC on the NSE has established contractual relationships not only with the board and shareholders but has also allowed entry of other principals interested in improved performance. Because the CEO and some directors (agents) own equity stock in the company, their interests are aligned with those of the owner (government), helping to drive performance. While the listing as an external governance mechanism incentivizes KPLC to remain profitable, solvent and with adequate working capital, a confluence of factors - such as non-cost reflective tariffs; overborrowing to finance the aggressive universal access programmes; the expensive cost of capital; delayed government subsidies, and internal mismanagement - have led to a decline in its financial performance. In this way, the principals' enduring conflict of interest in the governance of KPLC has had detrimental financial repercussions not only on KPLC but also on the capital markets. This requires a review and rethinking.

As with all research projects, data availability limitations especially on some macrolevel indices and incentives was experienced, and interviewees were out of necessity limited to top-level decision-makers (CEOs and Heads of Departments). Perhaps the inclusion of more middle management staff and officers would have provided additional information. One of the areas which further research can address is the welfare analysis of power sector reforms using a cost-benefit analysis. Further, a similar study in West Africa or Southern Africa would be interesting.

\section{Conclusion}

In conclusion, the Kenyan case provides fascinating insights on how legislative, regulatory, structural and governance reforms can create incentives for improved utility performance. However, the role of the principal, including in a mixed capital enterprise such as KPLC, remains critical. When the relationship between principal and agent is well understood and the agent is properly incentivized, performance improvements are possible. When the principal undermines or muddies those incentives through conflicting political interventions, performance improvements can be reversed.

Informed Consent Statement: Informed consent was obtained from interviewees prior to the interviews in accordance with the rules of the Declaration of Helsinki of 1975, revised in 2013 and the protocol was approved by the Ethics in Research Committee of the University of Cape Town Ref 2018001011

Data Availability Statement: The data presented in this study are available on request from the corresponding author due to ethical considerations. The qualitative data is kept private as it would reveal the identities of interviewees. Quantitative data can be obtained from reports cited in the references.

Funding: This research was funded by the University of Cape Town and the Konrad Adenauer Stiftung

Acknowledgments: This study benefited from administrative support of Power Futures Lab at the University of Cape Town

Conflicts of Interest: The author declares no conflict of interest.

\section{References}

[1] A. Eberhard, K. N. Gratwick, E. Morella, and P. Antmann, Independent power projects in Sub-Saharan Africa: Lessons from five key countries. Washington, DC: International Bank for Reconstruction and Development / The World Bank, 2016.

[2] C. Godinho and A. Eberhard, Learning from powesector reform: The case of Kenya. (WPS 8819) Policy Research Working Paper, Private Sector Development Department, World Bank, Washington, DC, 2019.

[3] KPLC, “Annual Report 2018,” Nairobi, 2018.

[4] A. Mussa, "The Presidential Task Force On The Review Of Power Purchase Agreements," mondaq, 2021. [Online]. 
Available: https://www.mondaq.com/fiscal-monetary-policy/1058040/the-presidential-task-force-on-thereview-of-power-purchase-agreements.

[5] Business Daily, "Kenya Power shareholders to miss dividends as profit hits 10-year low," Business Daily, Nairobi, 24-Nov-2018.

[6] The Star, "Empty pockets for Kenya Power shareholders as profits plunge," The Star, Nairobi, 27-Feb-2020.

[7] KPLC, "Abridged Report and Financial Statements for the Year Ended 30 Th June 2016 the Kenya Power and Lighting Company Limited," Nairobi, 2019.

[8] F. Muli, "Kenya Power Board Members Forced To Resign As Gov't Sets Up New Board," Kahawa Tungu, Nairobi, 14-Jul-2020.

[9] International Energy Agency, “Tracking SDG 7: The Energy Progress Report,” 2019.

[10] International Energy Agency, “Africa Energy Outlook 2019 - Analysis Scenarios," 2019.

[11] M. P. Blimpo and A. Postepska, "Why is Household Electricity Uptake Low in Sub-Saharan Africa?," Why is Househ. Electr. Uptake Low Sub-Saharan Africa?, pp. 1-41, 2017.

[12] M. Kojima, X. Zhou, J. J. Han, J. de Wit, R. Bacon, and C. Trimble, Who uses electricity in Sub-Saharan Africa? (WPS 7789) Policy Research Working Paper, Private Sector Development Department, World Bank, Washington, DC, 2016.

[13] C. Trimble, M. Kojima, I. Perez-Arroyo, and F. Mohammadzadeh, Financial viability of electricity sectors in subSaharan Africa: Quasi-fiscal deficits and hidden costs. (WPS 7788) Policy Research Working Paper, Private Sector Development Department, World Bank, Washington, DC, 2016.

[14] J. Huenteler, I. Dobozi, A. Balabanyan, and B. Sudeshna, "Cost Recovery and Financial Viability of the Power Sector in Developing Countries," Washington D.C., WPS8287, 2017.

[15] T. B. Andersen and C. J. Dalgaard, "Power outages and economic growth in Africa," Energy Econ., vol. 38, pp. 19-23, 2013.

[16] A. Eberhard, "Power investment trends and challenges in sub-Saharan Africa," no. March. Power Futures Lab, Graduate School of Business, University of Cape Town, 2020.

[17] A. Eberhard and G. Dyson, "Revisiting reforms in the power sector in Africa," African Development Bank Group, p. 72, 25-Sep-2019.

[18] K. N. Gratwick and A. Eberhard, "Demise of the standard model for power sector reform and the emergence of hybrid power markets," Energy Policy, vol. 36, no. 10, pp. 3948-3960, Oct. 2008.

[19] J. H. Williams and R. Ghanadan, "Electricity reform in developing and transition countries: A reappraisal," Energy, vol. 31, no. 6-7, pp. 815-844, 2006.

[20] V. Foster and R. Anshul, "Rethinking power sector reform in the developing world," World Bank: Understanding Poverty, Washington D.C., p. 356, 10-Sep-2019.

[21] J. E. Besant-Jones, Reforming power markets in developing countries: What have we learned? (Discussion Paper No. 19) Energy and Mining Sector Board, World Bank Group, 2006.

[22] A. Eberhard, K. N. Gratwick, E. Morella, and P. Antmann, "Independent power projects in Sub-Saharan Africa: Investment trends and policy lessons," Energy Policy, vol. 108, pp. 390-424, Sep. 2017.

[23] T. Jamasb, R. Nepal, G. Timilsina, and M. Toman, Energy sector reform, economic efficiency and poverty reduction. (Unpublished paper) School of Economics, University of Queensland, Australia, 2014.

[24] M. L. Polemis, "New evidence on the impact of structural reforms on electricity sector performance," Energy Policy, vol. 92, 2016.

[25] J. Urpelainen, J. Yang, and D. Liu, "Power sector reforms and technical performance: Good news from an instrumental variable analysis," Rev. Policy Res., vol. 35, no. 1, pp. 1-33, 2017. 
[26] Y. Zhang, D. Parker, and C. Kirkpatrick, "Electricity sector reform in developing countries: An econometric assessment of the effects of privatization, competition and regulation," J. Regul. Econ., vol. 33, no. 2, pp. 159-178, 2008.

[27] M. Saunders, P. Lewis, and A. Thornhil, Research Methods for Business Students, vol. 8, no. 4. 2019.

[28] A. Langley, "Strategies for Theorizing from Process Data," Acad. Manag. Rev., vol. 691, no. 4, pp. 691-710, 1999.

[29] A. L. George and A. Bennett, "Process Tracing in Case Study Research," October, pp. 104-105, 1997.

[30] G. A. Bowen, "Document analysis as a qualitative research method," Qual. Res. J., vol. 9, no. 2, pp. $27-40,2009$.

[31] E. Guba and Y. Lincoln, “Competing Paradigms in Qualitative Research.pdf." 1994.

[32] K. M. Eisenhardt, "Agency theory: An assessment and review," Acad. Manag. Rev., vol. 14, no. 1, pp. 57-74, 1989.

[33] E. F. Fama, "Agency problem and the theory of firm," J. Polit. Econ., vol. 88, no. 2, pp. 288-307, 1980.

[34] A. Eberhard, K. N. Gratwick, and L. Kariuki, "Kenya's lessons from two decades of experience with independent power producers," Util. Policy, vol. 52, pp. 37-49, Jun. 2018.

[35] Government of Kenya, "Economic Recovery Strategy for Wealth and Employment Creation (2003-2007)," Nairobi, 2003.

[36] Government of Kenya, "Sessional Paper No . 4 on Energy: National Energy Policy," 2004.

[37] J. Kapika and A. Eberhard, Power-sector reform and regulation in Africa: Lessons from Kenya, Tanzania, Uganda, Zambia, Namibia and Ghana. Cape Town, South Africa: HSRC Press, 2013.

[38] Government of Kenya, "The Energy Act No 1 of 2019," Kenya Gaz. Suppl. Acts, 2019, vol. 29, no. 29 , 2019.

[39] Government of Kenya, "5000 + MW IN 40 MONTHS POWER TO TRANSFORM KENYA Republic of Kenya," Nairobi, 2013.

[40] MoEP, “5000+ MW by 2016: Power to Transform Kenya,” 2013.

[41] Kenyan Wall Street, "Kenya Govt Halts Plan to Add 5000MW of electricity to National Grid," The Kenyan Wall Street, 2017. [Online]. Available: https://kenyanwallstreet.com/kenya-govt-halts-plan-install-5000mw-electricitynational-grid/.

[42] Africa Business Insight, "Power privatisation: Kenya case study," Africa Business Insight, Nairobi, 05-May-2016.

[43] Government of Kenya, Mwongozo: The Code of Governance for State Corporations. Nairobi, 2015.

[44] Business Daily, "Half of Kenya Power directors quit,” Business Daily, Nairobi, 14-Jul-2020.

[45] CMA-Kenya, The Capital Markets (Secutirties) (Public Offers, Listing and Disclosures) Regulations 2002- Amended 2019, no. May. Kenya: CMA, 2002, pp. 1-221.

[46] Government of Kenya, The Capital Markets Act: The Code of Corporate Governance Practices for Issuers of Securities to the Public 2015, vol. 11, no. 3. Nairobi, Kenya, 2015, pp. 1-38.

[47] J. Ngetich, "President Uhuru Kenyatta orders talks to lower cost of power," The Standard, Nairobi, $28-J u l-2016$.

[48] V. Juma, “Uhuru picks team to review Kenya Power's costly purchase deals,” Business Daily, Nairobi, 31-Mar2021.

[49] Government of Kenya, "Report of The Presidential Taskforce on Power Purchase Agreements," Nairobi, 2021.

[50] S. Fobi, V. Deshpande, S. Ondiek, V. Modi, and J. Taneja, "A longitudinal study of electricity consumption growth in Kenya," Energy Policy, vol. 123, no. November 2017, pp. 569-578, 2018.

[51] K. Lee et al., "Electrification for 'under Grid' households in Rural Kenya," Dev. Eng., vol. 1, pp. $26-35,2016$.

[52] World Bank, “Access to electricity (\% of population) - Kenya," 2018. [Online]. Available: https://data.worldbank.org/indicator/EG.ELC.ACCS.ZS?locations=KE. [Accessed: 21-Sep-2020].

[53] ESMAP, “Regulatory Indicators for Sustainable Energy,” 2018.

[54] B. Murefu, “The Problem with Kenya Power's Revenue Model in Three Graphs," Energy for Growth Hub, Aug2020. [Online]. Available: https://www.energyforgrowth.org/memo/the-problem-with-kenya-powers-revenue- 
model-in-three-graphs/.

[55] J. Anywanza, “Kenya Power issues profit alert as business declines," The East African, Nairobi, 22-Jun-2020.

[56] Business Daily, “Kenya Power gets external debt relief in cost cut push,” Business Daily, Nairobi, 06-Aug-2020. 